KEYWORDS

International trade

Exports

Export diversification

Economic growth

Emerging markets

Economic indicators

Trade statistics

Latin America

Caribbean

East Asia
CEPAL REVIEW 97 • APRIL 2009

\section{Export diversification and growth in emerging economies}

Manuel R. Agosin

$\mathrm{T}$

his paper develops and tests a model of growth that emphasizes the introduction of new exports as the main source of growth in countries that are well within the global technology frontier and depend for growth on adapting existing products to their economic environment. It seeks to capture the stylized facts behind growth in countries as different as the Republic of Korea, Taiwan Province of China, Mauritius, Finland, China and Chile, all of which have relied on export diversification. The widening of comparative advantage is thus seen as the main driver of economic growth. The export diversification hypothesis is tested using an empirical growth model. Controlling for other variables that affect growth, export diversification - both alone and in interaction with growth in per capita export volumes - is found to be highly significant in explaining per capita GDP growth over the 1980-2003 period.
Manuel R. Agosin

Professor,

Department of Economics,

School of Economics and Business, University of Chile

• managosin@econ.uchile.cl 


\section{I \\ Introduction}

This paper explores the connection between rising exports and GDP growth, with reference to the divergent growth experience of East Asian and Latin American and Caribbean countries. We are interested in the issue of whether export growth is associated with overall economic growth. In a statistical sense the relationship must hold, since exports are a part of GDP, but the focus here will be on whether there is a particular kind of export growth that can result in sustained growth both in exports and in GDP. We posit that countries with diversified export structures are able to record consistently higher export growth than countries whose exports are largely confined to just a few products.

Section II presents some analytical considerations on the question of why output and export diversification should be positive for growth. In section III, a model is developed to capture the stylized facts of an economy where growth is based on adaptation of foreign goods rather than on genuine innovation. After looking at the export and growth experience of Latin America and the Caribbean and Asia (section IV), we show the plausibility of a negative association between export concentration and growth owing to the effects of concentration on export and output volatility (section V). Then, in section VI, we show that an export diversification index and export growth interacting with this index (a sort of diversificationweighted export growth rate) are strong explanatory variables in a simple empirical growth model estimated with cross-section data for 1980-2003. In section VII, the coefficients yielded by the empirical model are used to estimate the average contribution of export diversification, investment and the rule of law to growth in Latin American and Asian countries. Section VIII recapitulates.

\section{II}

\section{Analytical considerations}

Why might export diversification be beneficial to growth? There are potentially two different types of effects. The first is what we call the portfolio effect, which takes its name from the financial literature. The greater the degree of diversification, the less volatile export earnings will be. Less volatile exports are associated with lower variance of GDP growth. This in itself is a positive aspect of diversification, since countries with imperfect (or no) access to world financial markets will not be able to smooth consumption in the face of large fluctuations in exports and output.

In addition, the variance and mean of the growth rate may be negatively correlated for other reasons. This adverse effect of volatility on average growth could result from hysteresis. Periods of contraction lead to the destruction of installed capacity and to deskilling of the labour force, neither of which can easily be undone during the next boom. Also, countries

$\square$ The author is grateful for the able research assistance of Alfie Ulloa and Alejandro Támola. A first version of this paper, eventually published as Agosin (2007), was presented at the "Economic growth with equity" seminar held at the headquarters of the Economic Commission for Latin America and the Caribbean (ECLAC) in Santiago, Chile on 1 and 2 September 2005 and at the All China Economics International Conference held in Hong Kong (Special 
whose exports are highly dependent on one or a few products tend to have more volatile real exchange rates than countries with diversified export structures, and real exchange-rate volatility discourages investment in tradable goods and services.

Second, there is the dynamic effect of export diversification. Long-run growth is associated with learning to produce an expanding range of goods. This view sees growth as resulting from the addition of new products to the export and production basket. In countries that have few indigenous sources of productivity growth, most productivity advances come from the investment process itself, as new capital goods embody changes in production methods and open up new sectors that have higher factor productivity than existing ones. These sectors are not new to the world, but they are new to the economy where they are being introduced and represent technical change.

One of the single most important characteristics of countries with low per capita income is that they have a comparative advantage in a very limited range of goods. In other words, paucity of skills or a lack of complementary inputs (some non-traded) mean that these countries are unable to apply production knowledge that exists elsewhere in the world. As a country develops, it becomes increasingly able to produce an ever wider range of goods and can begin to compete in international markets for them. Consequently, there is a line of causation that runs from per capita income to diversification of production and exports. While not the only one, the ability to export can certainly be judged a good indicator of international competitiveness.

But there may also be a causal relationship running from efforts to diversify exports to growth itself. The acquisition of new comparative advantages may be a powerful spur to more rapid economic growth. In other words, countries whose comparative advantages remain confined to a narrow range of low-technology goods grow slowly, and countries that are able to broaden their comparative advantages grow more rapidly. That is the major hypothesis of this paper.

Production of goods that represent a step up the technological ladder for a country requires trained labour, but the introduction of such goods also speeds up the training of workers, as those employed in the new ventures tend to train others. In addition, the introduction of a new type of production increases the likelihood that other new sectors will arise, as human capital employed in the new sector may well come up with new production ideas.
In some recent literature, it has been convincingly argued that producers do not have complete knowledge of the comparative advantages of their economies. There are elements of comparative advantage that are, so to speak, discovered in the process of producing a new good. On this view, introducing a new good to the export basket has an externality, because it reveals to other producers the underlying cost structure of the economy. However, in a developing-country context, the introduction of a new good or the application of a new technology is easily copied, because such technological innovations cannot be patented in the economy where they are introduced. Therefore, the leader will not reap all the benefits of his investment (Hausmann and Rodrik, 2003).

A similar strand of argument emphasizes the discovery of foreign demand (Vettas, 2000). Making a new product for export markets may reveal to domestic producers that there is demand in international markets for products that can be (or already are being) produced domestically. ${ }^{1}$ In fact, the introduction of a new good may create demand abroad for that good by making consumers aware of its existence and characteristics. Like cost discoveries, demand discoveries represent non-patentable innovations and, as such, can be easily copied. Again, there is an important externality here that can lead to a sustained spurt of growth.

A further development in the literature is the demonstration that producing a new export can have additional growth-enhancing effects. Export discoveries are not random, but follow some kind of sequence. Countries that become good at producing a particular export are likely to develop comparative advantages in related sectors. It has been observed that new exports cluster together or follow a pattern in time, examples being television sets, digital versatile discs (DVDs) and mobile phones in China, different varieties of fruit in Chile and different kinds of wearing apparel in East Asia and Central America. This phenomenon can be explained by the observation that clusters of goods tend to utilize the same or similar public goods (specific public institutions) and non-tradable inputs (roads, logistical services). Hence, an export discovery may facilitate the emergence of other new exports in the same or closely related sectors. This being

\footnotetext{
${ }^{1}$ A case in point is wine in Chile. While wine has been produced there since the seventeenth century, it was not until the mid-1980s that exports took off, mainly because a few entrepreneurs discovered that, with some modifications to production techniques, Chilean wine could be sold very profitably in Europe (Agosin and BravoOrtega, 2007).
} 
the case, an export discovery has not only positive intra-industry growth effects but also inter-industry spillovers (Hausmann and Klinger, 2007; Hausmann and Rodrik, 2006).
These hypotheses suggest that export diversification should indeed be associated with economic growth, with export diversification the cause and economic growth the effect.

\section{III}

\section{A model linking output and export diversification to growth}

The purpose of this model is to attempt to capture these stylized facts. In a sense, it seeks to flesh out the classic view of development as resulting from the "advantages of backwardness" (Gerschenkron, 1962). In other words, technologically backward economies can grow at fast rates simply by copying what already exists elsewhere and do not have to grow by pushing out the technology frontier. ${ }^{2}$ Some countries are able to reap the advantages of being inside the technology frontier, either because of the policies they apply or because institutional arrangements are favourable; others are not. However, introducing goods that exist elsewhere is an innovation that can easily be copied. Indeed, it is precisely this that provides the impetus for rapid economic growth. The inability to reap discovery benefits is also the key market failure that needs to be dealt with if an economy with these characteristics is to grow.

There is no aggregate production function and no technical change other than those embodied in the introduction of newer and more sophisticated goods. Aggregate output is the sum of the production value of all goods produced in the economy. Let us begin with an economy that produces one traditional good (say, sugar) using land and labour. Sugar is the numeraire of our economy (its price is unity). The introduction of any new good is the product of an idea, in the sense of "self-discovery" as the term is used by Hausmann and Rodrik (2003); in order to be profitable, any new idea requires the existence of sector-specific public goods ("infrastructure" for short). Thus, economic growth in a developing-country setting is hampered by an informational externality (since those who introduce a new idea are unable to reap all its benefits) and by

\footnotetext{
2 This is why calculating total factor productivity in developing economies makes so little sense.
}

a coordination problem (since without the requisite infrastructure new ideas cannot be profitable).

Following Romer (1993), aggregate production is the sum of all goods produced. Let us assume that factor endowment consists of land $(T)$, unskilled labour $(L)$ and initial human capital $\left(H_{0}\right)$. Sugar production uses land and labour but not human capital; all modern goods use labour and human capital but not land. There is an unlimited supply of unskilled labour, in the sense of Lewis (1954), so that we do not have to worry about running up against a labour shortage, and the wage is fixed at its subsistence level $(\bar{w})$.

$$
Y=F\left(T, L_{T}\right)+\sum_{j} \sum_{i} p_{i j} G_{i j}\left(L_{i j}, H_{i j} ; A_{i j}, B_{j}\right)
$$

$$
\text { where } \begin{aligned}
& B_{j}=0, A_{j}=0 \\
& B_{j}=1, A_{j}=0,1 \\
& j=1, \ldots \ldots, n \\
& i=1, \ldots \ldots, m
\end{aligned}
$$

For a product $G_{i j}$ to be generating output, the economy must have the supporting infrastructure $\left(B_{j}=1\right)$. This is a necessary but not sufficient condition. The sufficient condition is that an entrepreneur must be using the idea $\left(A_{i j}=1\right)$. If the sector-specific infrastructure is not in place, there cannot be any production $\left(A_{i j}=0\right)$. Investment in infrastructure in this model is a public-sector decision. Growth takes place through the introduction of new goods or through investment in existing non-traditional goods. We assume that sugar production does not increase. ${ }^{3}$

\footnotetext{
${ }^{3}$ An alternative assumption is that sugar production grows at the rate of world demand, i.e., at the rate of growth of world output multiplied by the income elasticity of demand, which is usually much lower than unity.
} 
This model captures the essentials of the experience of countries as different as the Republic of Korea (Amsden, 1989), Taiwan Province of China (Wade, 1990), Mauritius (Wellisz and Lam Shin Saw, 1993), Finland (Jäntti, Saari and Vartiainen, 2005) and Chile (Agosin, 1999; Agosin and Bravo-Ortega, 2007).

Human capital (other than the initial endowment) is on-the-job training. There is no firm-specific human capital. In other words, trained workers can migrate without any retraining costs to other modern sectors of the economy. Existing trained workers train others. Hence, the increase in human capital in any given period is proportional to the initial endowment plus the human capital that is employed in the modern sector of the economy. The economy may also import human capital through foreign direct investment. ${ }^{4}$ Formally, some of the products $\left(G_{i j}\right)$ may bring with them the human capital $\left(H_{i j}\right)$ needed for their production.

$$
\dot{H}=\mu\left(H_{0}+\sum_{j} \sum_{i} H_{i j}\right)
$$

New ideas are the key to growth in this economy. Because many new ideas are variations on existing ones, new ideas (and new production sectors) are a function of the number of ideas being exploited in the economy $\left(A_{n m}\right)$ and of the stock of human capital.

$$
\dot{A}=J\left(A_{n m} ; H_{0}+\sum_{j}+\sum_{i} H_{i j}\right)
$$

The public sector builds sector-specific infrastructure that enables the introduction of new ideas. We make the following assumptions: (i) the public sector balances its budget, (ii) all revenues come from taxing profits generated both in the modern sectors and in sugar production, (iii) government expenditures are either on investments in new infrastructure projects or in consumption $\left(\mathrm{C}_{\mathrm{G}}\right)$ and (iv) the cost of each infrastructure project is the same (and equal to $\lambda$ ). From the condition of public-sector budget balance, we can obtain the number of new infrastructure projects undertaken:

$$
\dot{B}=(\tau / \lambda)\left(\pi_{s}+\sum_{j} \sum_{i} \pi_{i j}\right)-C_{G} / \lambda
$$

\footnotetext{
${ }^{4}$ This is one of the roles assigned by Romer (1993) to foreign direct investment in his original formulation of the model.
}

In this model, new infrastructure projects generate growth. However, since they must be financed out of tax revenue and the tax rate decreases the net profits of enterprises in the modern sector, there is a trade-off between new infrastructure projects and investment by existing firms in the modern sector, since investment is financed from retained earnings. ${ }^{5} \mathrm{We}$ assume that in the modern sector, aftertax profits are fully reinvested in existing ventures. Aftertax profits in sugar are consumed.

When will a new product be introduced into the economy? Assume that a prospective entrepreneur borrows $C_{0}$ in period 0 to gather information about introducing a new idea into the economy. The entrepreneur also knows that capital of $C_{l}$ is needed to make the project operational and will borrow this in period 1 if and only if the project indeed turns out to be profitable after the requisite information has been obtained. The project yields a profit of $\pi_{i j}$ in period 2, but in period 1 the information needed to ensure the project is profitable becomes known to all potential entrepreneurs. ${ }^{6}$

Formally, and assuming risk neutrality, the entrepreneur will decide to gather information about the project if expected aftertax profits in period 2 exceed the search costs in period 0 and the capital investment costs in period 1 :

$$
(1-\tau) E\left(\pi_{i j}\right) \geq C_{0}(1+r+\varphi)^{2}+C_{1}(1+r+\varphi)
$$

where $r$ is the international interest rate and $\varphi$ the country risk premium. Alternatively, $r$ can be interpreted as the bank deposit rate and $\varphi$ as the spread between borrowing and lending rates.

If expected profits are normally distributed, with a sufficiently large number of draws, average realized profits will be equal to expected profits. All entrepreneurs draw their information from the same pool. Some will wind up with profits that satisfy (5) and some will not.

\footnotetext{
${ }^{5}$ As will be seen below, we have made the simplifying assumption that there is no capital in this economy and that new production requires an advance (say, to hire skilled and unskilled workers) which is repaid in the following period. For pioneers, there is an additional investment in information-gathering.

${ }^{6}$ This is a somewhat different setup from the one used by Hausmann and Rodrik (2003). Their model requires a period of monopoly so that the innovator can reap a rent. We require only that the prospective profits of the project be sufficient to at least cover the costs of searching and setting up production.
} 
The situation of a copycat investor is much more favourable, since he or she can wait to observe which projects are profitable. For a copycat investor, the condition for making an investment in a sector $A_{i j}$ which turns out to be profitable is:

$$
(1-\tau) \bar{\pi}_{i j} \geq C_{1}(1+r+\varphi)
$$

This implies that it pays to wait for others to make the self-discovery, which means that there will be suboptimal investment in discoveries.

Discoveries can be of two types. One has already been highlighted by Hausmann and Rodrik (2003): the discovery of costs, which is related to information on input-output coefficients in the sector. For simplicity, we assume that these coefficients are fixed. Formally, a cost-discovery problem tells us that the entrepreneur must form an expectation with regard to these coefficients which ex post may or may not take their ex ante expected values. Simplifying the notation by eliminating subscripts and making $C=C_{0}(1+r+\varphi)^{2}+C_{1}(1+r+\varphi):$

$$
(1-\tau) E(\pi)=(1-\tau)[p-\bar{w} E(l)-s E(h)] G \geq C
$$

The maximum levels of $l, h$ that yield a positive profit higher than the value of the investment $C$ can be mapped by converting (9) into an equality. An investment will be made if the combined values of $l$ and $h$ are such that they are within the triangle in figure 1, where $\bar{C}=p-C /[G(1-\tau)]:^{7}$

If the entrepreneur draws input-output coefficients which do not fall within the triangle, the investment will not be profitable. In addition, since each entrepreneur is small, she does not take into account the effect of her investment on the skilled labour wage rate. However, one of the effects of cost discovery will be that investments by copycats push up this wage, reducing ex post the return on capital for the pioneer investor. An increase in the skilled labour wage will result in an inward movement within the input-output frontier, but only on the $h$ axis, as described by the dotted line in figure 1.

In addition, under certain circumstances, if the country's producers as a group face a downward-

\footnotetext{
${ }^{7}$ For the problem to have a sensible solution, must be positive $\bar{C} / \bar{w}, \bar{C} / s$.
}

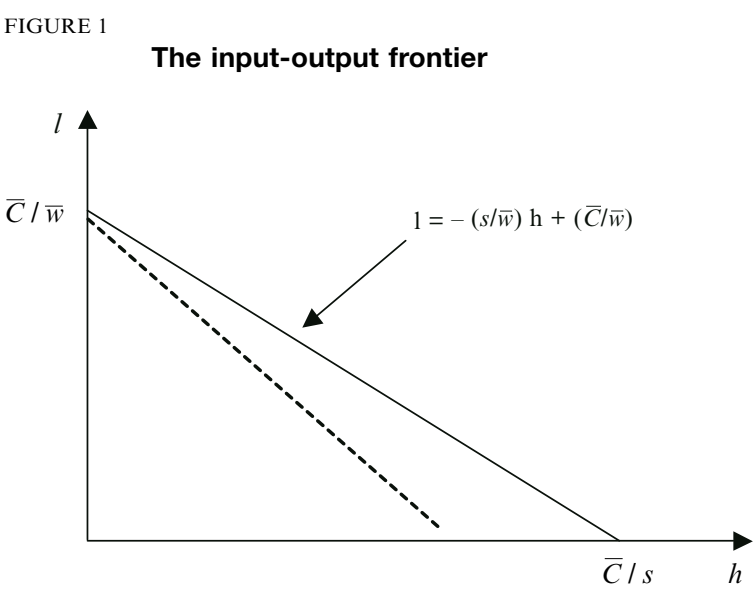

Source: author's calculations.

sloping demand curve, the product price may fall. ${ }^{8}$ In this case the entire input-output frontier will move inward towards the origin. If the tax rate increases, the input-output frontier will also move inward, making investment in discovery less likely.

But, as noted above, there is another kind of discovery: demand discovery. Entrepreneurs may know the cost structure of a particular good but be uncertain as to whether they can sell it abroad. Once a market for the product has been created abroad, other producers can take advantage of the discovery without incurring the costs of opening up the market. In this case, the investment decision will look like this:

$$
(1-\tau) E(\pi)=(1-\tau)[E(p)-\bar{w} l-s h] G \geq C
$$

In this case, there is a minimum price that makes the venture profitable, and that happens when the equality in (8) holds. As copycats enter the market for the discovered product, the skilled labour wage will be bid up and the product price may fall. In equilibrium, this will reduce the profits of pioneer and copycats alike and discourage discoveries.

We have thus seen that the actions of followers erode the profits of the pioneer, either by raising factor rewards or by reducing the product price. However, the source of the market failure remains the same:

\footnotetext{
${ }^{8}$ This is a far from hypothetical case. In Chile, the discovery of kiwis as an export product in the 1970s led in a few years to a collapse in the international price from which domestic producers did not recover until the late 1980 s.
} 
the pioneer takes risks that, if successful, result in easier profits for others. Therefore, it pays to wait for others to make the discoveries, and the supply of self-discovery will be suboptimal.

This model has interesting properties. When only sugar production exists, the potential for opening up new sectors is restricted to the resources the government can extract from taxing sugar profits, which are anyway not reinvested. Therefore, there might be a good argument for squeezing profits in the traditional sector, which (in the model) would have the result of lowering consumption and raising investment in infrastructure specific to other (new) sectors of the economy. At any rate, the potential for the introduction of new products into the economy is limited by the narrow tax base. As the tax base widens with the opening up of new sectors, the government is able to finance new infrastructure projects, thus accelerating growth. There is, nonetheless, a trade-off between building new infrastructure and opening up new sectors and investment by the private sector in the existing modern sectors.

Human capital formation is the consequence of new ideas being introduced and existing skilled workers training unskilled workers. A high rate of investment in human capital (with the effect of raising $\mu$, in our model) can ease the pressure on the skilled labour wage that is a consequence of investment in the modern sector and of the discovery of new products. In addition, the higher the rate of human capital accumulation, the higher will be the rate of new discoveries.

In this model, government has three roles: investing in infrastructure specific to sectors that do not yet exist, which makes discovery possible; subsidizing the cost of discovery, in light of the informational market failure involved; and raising the rate of skill formation (presumably by raising the value of $\mu$ ). ${ }^{9}$ As already noted, it should balance the need for public investment with

9 The costs of the last two have not been factored into the model. the drag of taxes on modern-sector investment, which is financed largely out of retained earnings. ${ }^{10}$

The model can account for several of the constraints on growth discussed in the literature and can be used to illustrate the decision-tree approach to the issue employed by Hausmann, Rodrik and Velasco (2005). For example, growth can be constrained by a high cost of finance. This would be reflected in an interest-rate spread $(\varphi)$ that would raise the threshold for the expected profits required for self-discovery activities. ${ }^{11}$ The economy may not be generating enough growth through discovery because of low appropriability of returns to discovery. This could be the case if the tax rate is too high, as this would reduce the rate of return to investments in new products. ${ }^{12}$ While taxes finance infrastructure investment, they can also finance consumption. The rate of new skill formation may be too low to prevent the wages of skilled labour from rising to levels where they choke off investment. This would be reflected in a low $\mu$ in equation (2).

These considerations may explain why successful countries are able to grow faster than others: they may subsidize discovery activities in various ways; they may keep borrowing costs low, either through policies that deepen financial markets or by directing credits to winners (see Amsden, 1989, for the Korean experience); they may use government revenue for investment rather than consumption; they may keep tax rates reasonable; or they may invest in human capital accumulation. Most of the successful countries of Asia have done some or all of these things, but Latin American countries have failed to do enough of them to ensure an adequate rate of self-discovery.

\footnotetext{
${ }^{10} \mathrm{We}$ are assuming that investment in existing modern sectors is financed out of retained earnings, but that the funds required to set up a new sector are borrowed.

${ }^{11}$ If non-availability of credit for new projects is the problem, then $\varphi$ is in effect infinite.

${ }^{12}$ Remember that taxes on sugar profits do not matter because these are consumed, but if taxes were high they would affect profits on both traditional and new products. Taxation on the latter discourages investment by reducing the appropriability of returns.
} 


\section{IV}

\section{Trade and growth in Latin America and the Caribbean and Asia, 1980-200313}

In this section, we show the plausibility of the hypothesis linking export diversification and growth by looking at the recent experience of East Asia and Latin America and the Caribbean. As shown in table 1, Asian exporters of manufactures grew much faster during 1981-2003 than Latin America and the Caribbean. Asian output and exports grew more than twice as fast as those of Latin America and the Caribbean. Even if one excludes the 1980s, the "lost decade" in the latter region, these differences also apply to the period since 1990, although average Asian output and export growth rates are not quite double those of Latin America and the Caribbean. Figure 2 shows that these averages are not a statistical fluke, since the same pattern repeats itself at the country level: all Asian countries exhibit higher rates of growth in both GDP and exports. Even during the
1991-2003 period, the country with the highest rate of GDP growth in Latin America and the Caribbean (Chile) was surpassed by five of the ten Asian countries included in the sample.

What is interesting about these figures is that both GDP and exports consistently grew faster in the Asian countries than in Latin America and the Caribbean. In fact, the ratio of GDP growth to export growth is practically identical in the two regions for the two periods analysed but, as argued below, Asian countries' exports not only grew faster but were also of higher "quality"; that is, they were considerably more diversified.

Of course, this does not mean that faster export growth is the key to the success of the Asian countries relative to their Latin American counterparts, since there are many other differences between them, but

TABLE 1

Latin America and the Caribbean and Asia (selected countries): GDP and export growth, 1981-2003

(Percentage annual change in GDP and real exports of goods and services)

\begin{tabular}{|c|c|c|c|c|}
\hline & \multicolumn{2}{|c|}{$1981-2003$} & \multicolumn{2}{|c|}{$1991-2003$} \\
\hline & GDP & Exports & GDP & Exports \\
\hline \multicolumn{5}{|l|}{ Growth rates } \\
\hline Latin America and the Caribbean & 2.4 & 5.3 & 3.0 & 6.2 \\
\hline Asia & 5.9 & 11.1 & 5.5 & 11.7 \\
\hline \multicolumn{5}{|l|}{ Ratio of GDP to export elasticity } \\
\hline Latin America and the Caribbean & \multicolumn{2}{|c|}{0.49} & \multicolumn{2}{|c|}{0.45} \\
\hline Asia & \multicolumn{2}{|c|}{0.47} & \multicolumn{2}{|c|}{0.53} \\
\hline
\end{tabular}

Source: author's calculations based on World Bank, World Development Indicators [online database] http://devdata.worldbank. org/dataonline/.

N.B.: Exports refer to real exports of goods and services (nominal values deflated by the relevant GDP deflator). Countries included are: in Latin America and the Caribbean, Argentina, Bolivarian Republic of Venezuela, Brazil, Chile, Colombia, Costa Rica, Dominican Republic, Ecuador, El Salvador, Guatemala, Honduras, Mexico, Nicaragua, Panama, Paraguay, Peru, Plurinational State of Bolivia and Uruguay; in Asia, Bangladesh, China, Hong Kong (SAR), India, Indonesia, Malaysia, Philippines, Republic of Korea, Thailand and Vietnam. ${ }^{13}$ The $2004-2007$ period was affected by the unprecedented rise in
primary commodity prices, which undoubtedly raised the Herfindahl-
Hirschmann coefficients of Latin America to levels considerably higher than those considered "normal" for the region. 


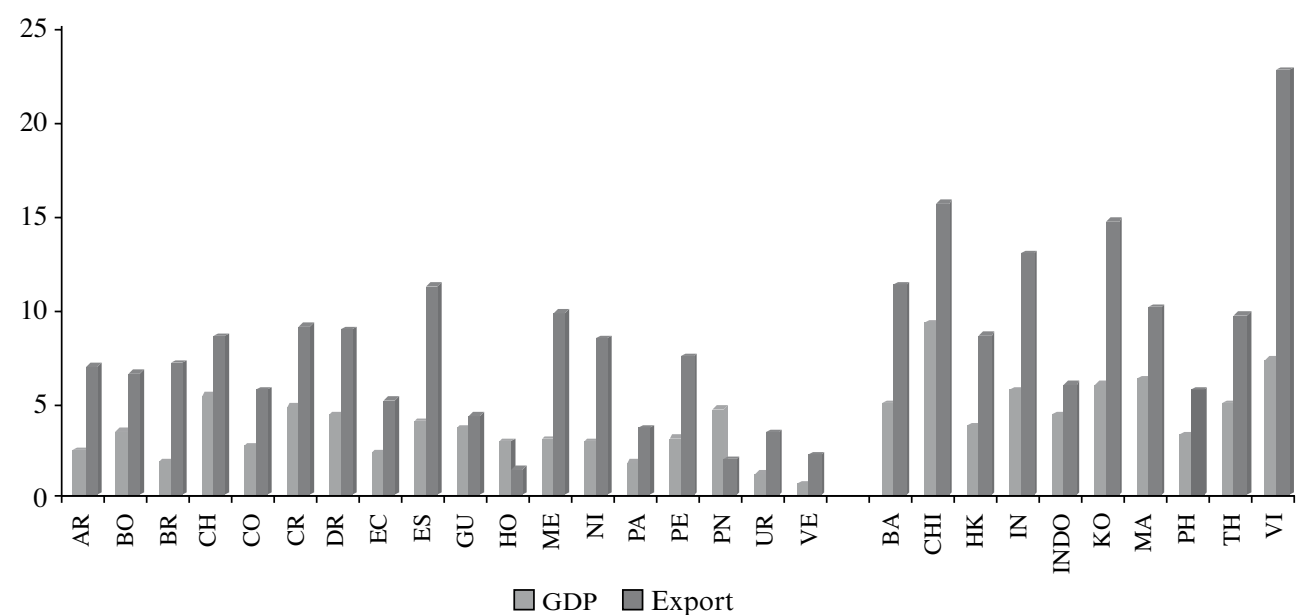

Source: author's calculations based on World Bank, World Development Indicators [online database] http://devdata.worldbank. org/dataonline/.

N.B.: Country abbreviations are as follows: in Latin America and the Caribbean, Argentina (AR), Plurinational State of Bolivia (BO), Brazil (BR), Chile (CH), Colombia (CO), Costa Rica (CR), Dominican Republic (DR), Ecuador (EC), El Salvador (ES), Guatemala (GU), Honduras (HO), Mexico (ME), Nicaragua (NI), Paraguay (PA), Peru (PE), Panama (PN), Uruguay (UR) and Bolivarian Republic of Venezuela (VE); in Asia, Bangladesh (BA), China (CHI), Hong Kong Special Administrative Region (HK), India (IN), Indonesia (INDO), Republic of Korea (KO), Malaysia (MA), Philippines (PH), Thailand (TH) and Vietnam (VI).

faster export growth, more diversified exports and the factors that underlie these phenomena do appear to have played a role.

There is evidence that output and export diversification has been a trait in the development pattern of Asia. The proxy for output and export diversification that we use here is the HerfindahlHirschmann Index (HHI), ${ }^{14}$ taken from the Handbook of Trade and Development Statistics of the United Nations Conference for Trade and Development (UNCTAD) and measured at the three-digit Standard International Trade Classification (SITC) level. However imperfectly, this indicator captures both vertical and horizontal diversification. By vertical diversification is meant the shift from exporting, say, primary commodities to exporting manufactures. Horizontal diversification means broadening the

\footnotetext{
14 The HHI for country $j$ is defined in the following manner: $H H I I_{j}=\sum_{i}\left(\frac{x_{i j}}{x_{j}}\right)^{2}$, where $x_{i j}$ is the value of exports of good $i$ by country $j$ and $x_{j}$ represents the total value of exports from country $j$.
}

export basket by diversifying into goods within the same broad category; for example, from grapes with seeds to seedless grapes, or from coffee for the mass market to gourmet coffee.

As can be seen from table 2, in 1980 Asian countries had a much lower HHI on average than Latin America and the Caribbean; during the period up to 2002 the index declined consistently in all Asian countries, with the exceptions of Taiwan Province of China and the Republic of Korea, where the HHI bottomed out in $1992 .{ }^{15}$ However, in 2002 these two latter economies had a lower HHI than most of Latin America and the Caribbean. Indonesia, a country whose exports were dominated by oil in 1980, saw a dramatic fall in its HHI over the 1980-2002 period, from 0.53 to 0.12 . China too, even after starting out

\footnotetext{
15 These two economies have the highest per capita incomes in the entire sample of middle-income countries, Asian or Latin American. In fact, the International Monetary Fund classifies them as developed economies. Perhaps the rise in the HHI is evidence of the U-shaped relationship between industrial concentration and income levels found by Imbs and Wacziarg (2003).
} 
TABLE 2

Latin America (selected countries) and Asian exporters of manufactures:

Herfindahl-Hirschmann export concentration index, 1980-2002

\begin{tabular}{|c|c|c|c|c|c|}
\hline & 1980 & 1986 & 1992 & 1998 & 2002 \\
\hline Latin America ${ }^{a}$ & 0.36 & 0.40 & 0.30 & 0.26 & 0.25 \\
\hline Argentina & 0.15 & 0.17 & 0.15 & 0.13 & 0.14 \\
\hline Bolivia (Plurinational State of) & 0.39 & 0.52 & 0.32 & 0.20 & 0.25 \\
\hline Brazil & 0.15 & 0.12 & 0.09 & 0.09 & 0.09 \\
\hline Chile & 0.41 & 0.37 & 0.31 & 0.28 & 0.27 \\
\hline Colombia & 0.58 & 0.58 & 0.24 & 0.25 & 0.22 \\
\hline Costa Rica & 0.32 & 0.39 & 0.30 & 0.19 & 0.21 \\
\hline Ecuador & 0.55 & 0.45 & 0.47 & 0.35 & 0.39 \\
\hline El Salvador & 0.38 & 0.71 & 0.24 & 0.24 & 0.13 \\
\hline Guatemala & 0.31 & 0.47 & 0.22 & 0.24 & 0.19 \\
\hline Honduras & 0.37 & 0.50 & 0.46 & 0.44 & 0.20 \\
\hline Mexico & 0.48 & 0.27 & 0.15 & 0.11 & 0.13 \\
\hline Nicaragua & 0.37 & 0.52 & 0.29 & 0.32 & 0.18 \\
\hline Panama & 0.26 & 0.37 & 0.45 & 0.30 & 0.31 \\
\hline Paraguay & 0.28 & 0.40 & 0.36 & 0.43 & 0.38 \\
\hline Peru & 0.26 & 0.25 & 0.27 & 0.22 & 0.25 \\
\hline Uruguay & 0.24 & 0.20 & 0.18 & 0.17 & 0.19 \\
\hline Venezuela (Bol. Rep. of) & 0.67 & 0.57 & 0.56 & 0.49 & 0.75 \\
\hline Asian exporters of manufactures ${ }^{a}$ & 0.22 & 0.17 & 0.13 & 0.14 & 0.14 \\
\hline China & $\ldots$ & 0.17 & 0.08 & 0.07 & 0.09 \\
\hline Hong Kong (SAR) & 0.16 & 0.16 & 0.15 & 0.18 & 0.12 \\
\hline Taiwan Province of China & 0.12 & 0.10 & 0.09 & 0.14 & 0.15 \\
\hline India & 0.11 & 0.16 & 0.14 & 0.14 & 0.13 \\
\hline Indonesia & 0.53 & 0.34 & 0.19 & 0.16 & 0.12 \\
\hline Republic of Korea & 0.09 & 0.10 & 0.11 & 0.15 & 0.15 \\
\hline Malaysia & 0.30 & 0.23 & 0.16 & 0.20 & 0.22 \\
\hline Thailand & 0.20 & 0.14 & 0.09 & 0.11 & $\ldots$ \\
\hline
\end{tabular}

Source: United Nations Conference on Trade and Development (UNCTAD), Handbook of Trade and Development Statistics, Geneva.

a Unweighted average of countries shown.

with a relatively low HHI in 1986, experienced a large decline to less than 0.10 , the kind of level observed in most developed countries. Most Asian exporters of manufactures are rapidly approaching HHI levels very similar to those of developed countries.

Several Latin American and Caribbean countries have been diversifying their exports. Particularly impressive has been the decline in the HHI of Mexico, Colombia and, to a lesser extent, Chile. Argentina maintained a low HHI for the entire 1980-2002 period, but its exports remain more concentrated than those of Asian manufacturing exporters.

Practically the same picture emerges if one looks at the number of goods exported, also at the SITC three-digit level (see table 3). The maximum number of positions in the three-digit SITC is 239 and practically all Asian countries are fast approaching that number. While an increase in the number of goods exported can also be seen in Latin America and the Caribbean, it has been more modest, so that the average remains at about half the maximum. ${ }^{16}$

\footnotetext{
${ }^{16}$ A curiosity of the data is that the number of products exported by most Latin American countries actually declined during the first half of the 1980s. This could have been another effect of the debt crisis.
} 
Latin America (selected countries) and Asian exporters of manufactures: number of goods exported, 1980-2002

(At the three-digit level of the Standard International Trade Classification)

\begin{tabular}{|c|c|c|c|c|c|}
\hline & 1980 & 1986 & 1992 & 1998 & 2002 \\
\hline Latin America $^{a}$ & 141 & 112 & 142 & 163 & 169 \\
\hline Argentina & 198 & 201 & 211 & 221 & 220 \\
\hline Bolivia (Plurinational State of) & 47 & 42 & 82 & 119 & 130 \\
\hline Brazil & 225 & 213 & 219 & 222 & 225 \\
\hline Chile & 181 & 147 & 195 & 209 & 201 \\
\hline Colombia & 162 & 149 & 189 & 197 & 201 \\
\hline Costa Rica & 144 & 113 & 142 & 179 & 175 \\
\hline Ecuador & 80 & 53 & 116 & 148 & 151 \\
\hline El Salvador & 116 & 86 & 113 & 149 & 164 \\
\hline Guatemala & 168 & 121 & 137 & 167 & 168 \\
\hline Honduras & 99 & 56 & 90 & 120 & 131 \\
\hline Mexico & 201 & 208 & 221 & 229 & 229 \\
\hline Nicaragua & 97 & 41 & 63 & 86 & 137 \\
\hline Panama & 136 & 64 & 75 & 88 & 120 \\
\hline Paraguay & 63 & 24 & 61 & 90 & 94 \\
\hline Peru & 176 & 135 & 162 & 187 & 190 \\
\hline Uruguay & 156 & 130 & 149 & 166 & 150 \\
\hline Venezuela (Bol. Rep. of) & 153 & 128 & 193 & 196 & 194 \\
\hline Asian exporters of manufactures ${ }^{a}$ & 189 & 182 & 212 & 217 & 225 \\
\hline China & $\ldots$ & 90 & 233 & 232 & 233 \\
\hline Hong Kong (sar) & 164 & 165 & 175 & 179 & 227 \\
\hline Taiwan Province of China & 210 & 214 & 219 & 221 & 219 \\
\hline India & 211 & 205 & 214 & 222 & 227 \\
\hline Indonesia & 144 & 154 & 208 & 216 & 227 \\
\hline Republic of Korea & 207 & 212 & 215 & 220 & 217 \\
\hline Malaysia & 214 & 217 & 222 & 227 & 224 \\
\hline Thailand & 176 & 197 & 211 & 222 & $\ldots$ \\
\hline
\end{tabular}

Source: United Nations Conference on Trade and Development (UNCTAD), Handbook of Trade and Development Statistics, Geneva.

a Unweighted average of countries shown.

\section{Evidence for the portfolio effect}

The portfolio effect of output and export diversification on growth should mean that export diversification is associated with faster growth. If the portfolio effect were indeed at work, the causal relationships would be those summarized in figure 3. Export diversification is related positively to growth because of its effect in reducing the variance of export and GDP growth. As already stated, a reduction in the volatility of GDP growth should have a positive effect on growth itself.

These hypotheses are not falsified by the data available for the 1980-2003 period. Figure 3 would lead one to expect a negative correlation between export diversification and the variance of export growth, a positive correlation between the variance of export growth and the variance of GDP growth, and a negative correlation between the variance of GDP growth and the rate of GDP growth. ${ }^{17}$

\footnotetext{
${ }^{17}$ Part of the effect of high GDP volatility on the GDP growth rate could be due to the impact of volatility on investment. High GDP volatility can be expected to lead to low rates of investment, with low investment being the cause of slow growth.
} 
This is precisely what the data show (see figure 3). All correlation coefficients are of the expected sign and are significantly different from zero at the $1 \%$ level. Export diversification is measured as $D I V=1-H H I$. Increases in $D I V$ are highly correlated with declines in the variance of export growth. In turn, a lower variance of export growth is highly correlated with a lower variance of GDP growth. Lastly, a lower variance of GDP growth is strongly associated with higher GDP growth.

These simple correlations do not amount to proof of the portfolio effect, but they do suggest that something like it may indeed be at work.

FIGURE 3

The portfolio effect of export diversification on growth, 1980-2003a

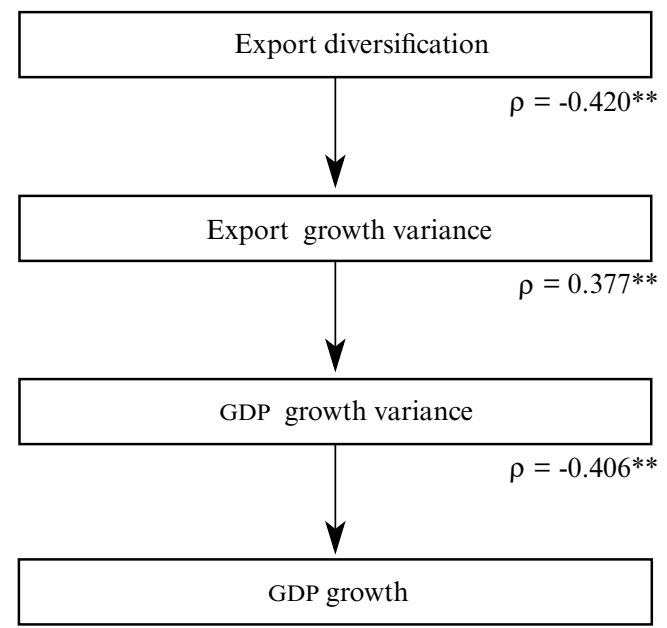

Source: World Bank, World Development Indicators [online database] http://devdata.worldbank.org/dataonline/, and United Nations Conference on Trade and Development (UNCTAD), Handbook of Trade and Development Statistics, Geneva.

a The values of $\rho$ represent the correlation coefficients between the variables in the two adjacent boxes. All are significant at the $1 \%$ level. The data used are for 106 countries over the 1980-2003 period. Export growth refers to goods and services in 2000 dollars. GDP growth data are in 2000 dollars.

\section{VI \\ Growth empirics: does export diversification add anything?}

In this section, we explore whether export diversification has any explanatory power in a parsimonious empirical model of growth. Two different variables, proxies for output and export diversification, were tested. One was DIV by itself, while the other was diversificationweighted per capita export growth; in other words, $D I V$ interacting with per capita export growth $\left(R X^{*} D I V\right)$. As will be noted below, while $D I V$ has the correct sign and is highly significant, it is the interactive variable that has the most explanatory power. The intuition behind the inclusion of this interactive variable is that diversification is more powerful when a country's exports are growing rapidly than just by itself. Note the difference between Colombia and Malaysia: both wind up in 2002 with a $D I V$ of 0.78 ( $H H I$ of 0.22 ), but Malaysia's exports grew at a rate of $10.7 \%$ in the 1980-2003 period, while Colombia's grew only at an average rate of $5.7 \%$. Diversification-weighted per capita exports in Malaysia grew at an annual rate of $5.9 \%$, while those of Colombia grew by only $2.5 \%$ a year. GDP growth averaged $6.4 \%$ in Malaysia but only $3.1 \%$ in Colombia. 
The estimation strategy is to add $D I V$ and $R X^{*} D I V$ to an otherwise standard empirical model of per capita growth. The variables considered were initial GDP per capita, initial openness (trade as a percentage of GDP), average fixed capital formation during the period, and the rule of law index from the database developed by Kaufmann, Kraay and Mastruzzi (2003). ${ }^{18}$ The model is estimated by ordinary least

\footnotetext{
${ }^{18}$ A host of different controls were also used, including the average years of schooling in the population aged 15 to 64 , but they were not found to add anything to the equation.
}

squares (OLS) and by instrumental variables (IV). This latter technique is used to correct possible simultaneity biases stemming from the endogeneity of the growth rate, export diversification and the investment rate. The instruments used for the investment rate and for $D I V$ and $R X^{*} D I V$ were manufactures as a share of exports, population size and the rule of law index.

The most suggestive results of the exercise are shown in table 4. In equations (1) and (2), we control only for initial GDP per capita and openness. DIV and $R X^{*} D I V$ are of the correct sign and highly significant when entered individually into the regression. The inclusion of both $D I V$ and $R X^{*} D I V$ in an equation (not

TABLE 4

An empirical model of growth

(Dependent variable: average annual rate of per capita gdp growth, 1980-2003)

\begin{tabular}{|c|c|c|c|c|c|c|c|c|}
\hline \multirow[t]{2}{*}{ Explanatory variable } & \multicolumn{2}{|c|}{ (1) } & \multicolumn{2}{|c|}{ (2) } & \multicolumn{2}{|c|}{ (3) } & \multicolumn{2}{|c|}{ (4) } \\
\hline & OLS & IV & OLS & IV & OLS & IV & OLS & IV \\
\hline $\log$ YPC80 & $\begin{array}{c}-0.102 \\
(-0.87)\end{array}$ & $\begin{array}{c}-0.366 \\
(-2.57)^{*}\end{array}$ & $\begin{array}{c}-0.014 \\
(-0.16)\end{array}$ & $\begin{array}{l}-0.080 \\
(-0.72)\end{array}$ & $\begin{array}{c}-0.800 \\
(-6.99)^{* *}\end{array}$ & $\begin{array}{c}-0.717 \\
(-5.41)^{* *}\end{array}$ & $\begin{array}{c}-0.683 \\
(-5.94)^{* *}\end{array}$ & $\begin{array}{c}-0.581 \\
(-3.92)^{* *}\end{array}$ \\
\hline TRADE80 & $\begin{array}{c}0.006 \\
(1.51)\end{array}$ & 0.014 & $\begin{array}{c}0.005 \\
(1.62)\end{array}$ & $\begin{array}{c}0.006 \\
(1.68)+\end{array}$ & $\begin{array}{c}-0.001 \\
(-0.44)\end{array}$ & $\begin{array}{r}0.000 \\
(0.01)\end{array}$ & $\begin{array}{c}-0.000 \\
(-0.01)\end{array}$ & $\begin{array}{r}0.003 \\
(0.83)\end{array}$ \\
\hline $\mathrm{I} / \mathrm{Y}$ & & & & & $\begin{array}{c}0.192 \\
(9.12)^{* *}\end{array}$ & $\begin{array}{c}0.249 \\
(4.88)^{* *}\end{array}$ & $\begin{array}{l}0.159 \\
(6.49)^{* *}\end{array}$ & $\begin{array}{c}0.119 \\
(3.09)^{* *}\end{array}$ \\
\hline $\mathrm{RL}$ & & & & & $\begin{array}{c}1.345 \\
(7.30)^{* *}\end{array}$ & $\begin{array}{c}0.949 \\
(3.48)^{* *}\end{array}$ & $\begin{array}{c}1.198 \\
(6.41)^{* *}\end{array}$ & $\begin{array}{c}0.911 \\
(3.53)^{* *}\end{array}$ \\
\hline DIV & $\begin{array}{c}4.646 \\
(5.12)^{* *}\end{array}$ & $\begin{array}{l}12.147 \\
(4.71)^{* *}\end{array}$ & & & $\begin{array}{l}2.309 \\
(3.59)^{* *}\end{array}$ & $\begin{array}{l}5.05 \\
(2.92)^{* *}\end{array}$ & & \\
\hline RX*DIV & & & $\begin{array}{c}0.326 \\
(9.37)^{* *}\end{array}$ & $\begin{array}{c}0.465 \\
(9.26)^{* *}\end{array}$ & & & $\begin{array}{c}0.176 \\
(5.43)^{* *}\end{array}$ & $\begin{array}{c}0.312 \\
(5.65)^{* *}\end{array}$ \\
\hline Adj. R2 & 0.165 & - & 0.427 & 0.365 & 0.655 & 0.608 & 0.677 & 0.640 \\
\hline No. of observations & 124 & 118 & 118 & 117 & 113 & 112 & 109 & 108 \\
\hline
\end{tabular}

Source: World Bank, World Development Indicators [online database] http://devdata.worldbank.org/dataonline/, except for the HerfindahlHirschmann Index data, which are from United Nations Conference on Trade and Development (UNCTAD), Handbook of Trade and Development Statistics, Geneva.

N.B.: Underlying GDP and export data are in constant 2000 dollars. Exports refer to goods and services. The rule of law index is from Kaufman, Kraay and Mastruzzi (2005) and was measured in 1996. Constant not shown; $t$ ratios in parentheses; IV estimations with robust standard errors.

* $\quad$ Significantly different from zero at the $10 \%$ level.

** $\quad$ Significantly different from zero at the $5 \%$ level.

*** Significantly different from zero at the $1 \%$ level.

Definition of variables:

YPC80 = GDP per capita in 1980.

TRADE80 = exports plus imports divided by GDP in 1980

$\mathrm{I} / \mathrm{Y}=$ gross fixed capital formation (average for the period) as a share of GDP.

RL $\quad=$ rule of law index (1996).

DIV = export diversification index (1- HHI), average for the period (data end in 2002).

RX*DIV = diversification-weighted rate of per capita export growth.

Instrumental variables used for DIV, RX*DIV and I/Y: share of manufactures in GDP, population size and rule of law. 
shown) renders DIV not significantly different from zero, while the coefficient associated with $R X^{*} D I V$ remains almost unchanged and is still highly significant. Interestingly, the share of trade in initial GDP plays no role in explaining cross-country variations in per capita GDP growth rates. Neither is initial income per capita a robust explanatory variable, as the significance of the coefficient attached to this variable fluctuates quite sharply between model specifications and estimation techniques. As we shall see, this result is overturned when we add control variables to the model.

Next, we introduce $D I V$ and $R X^{*} D I V$ into a more completely specified model, one that includes gross fixed investment and the rule of law index. This is done in equations (3) and (4). It can be seen that this parsimonious model is statistically quite powerful. Initial GDP per capita becomes highly significant, the openness variable continues to have no role in the explanation of cross-country growth differences, and investment and the rule of law are both of the correct sign and also highly significant. These results confirm the finding in the literature that growth is positively related to investment, a hypothesis that goes back to the Harrod-Domar model and is also compatible with some of the more recent endogenous growth literature. ${ }^{19}$ The results also lend credence to the more recent emphasis on institutions as important determinants of growth.
The rule of law $(R L)$ is only as good as the capacity of governments to enforce it, and such capacity is likely to depend on a basic social pact. Other things being equal, countries where the government is perceived as working for the good of society as a whole are better able to enforce the rule of law, and this may explain the result that higher levels in $R L$ are positively correlated with growth, and that the coefficient associated with $R L$ is highly significant.

Both the variables that attempt to capture output and export diversification ( $D I V$ and $R X^{*} D I V$ ) are highly significant, the interactive variable more so than $D I V$. Note that the model explains between $60 \%$ and two thirds of the cross-country variation in per capita gdp growth rates. Instrumental variable estimations raise the value of the coefficients attached to diversification and diversification-weighted per capita export growth. In equation (3), the coefficient of DIV doubles. In equation (4), the coefficient of $R X^{*} D I V$ rises just shy of $100 \%$. At the same time, the coefficients of the other variables remain more or less stable when we go from OLS to IV estimations. This would seem to support the notion that export diversification, in either of its two formulations, has indeed been an important contributor to the differences in growth performance between Asia and Latin America and the Caribbean.

\section{VII}

\section{Growth differentials: how much does output and export diversification explain?}

Even if the coefficients attached to our proxies of output and export diversification are statistically significant, they may not add much to the explanation of growth differentials. Through a simple exercise using the regional average values of $D I V, R X^{*} D I V, I / Y$ and $R L$, we can show that our two output and export

\footnotetext{
${ }^{19}$ Ironically, the profession rediscovered Harrod-Domar in the guise of the AK model. Since economists do not have much historical memory, however, nobody has remarked that the ak model is nothing other than the Harrod-Domar model in a new guise. Since much of the growth in productivity in developing countries comes embodied in imported machinery, the importance of investment is likely to be even greater for this group of countries than for developed economies.
}

diversification variables do explain a quantitatively important share of the difference in growth performance between exporters of manufactures in Asia and Latin America and the Caribbean.

First let us look at what the data for our main variables tell us about these variables that purportedly explain differences in growth performance. As can be seen in table 5, the rate of per capita gdp growth was quite robust in the Asian high performers, but very modest in Latin America and the Caribbean. Asia has done better than Latin America and the Caribbean in all explanatory factors, but two stand out: investment rates are almost 9 percentage points of gdp higher in Asia, and average diversificationweighted per capita export growth is 6.7 percentage 
Latin America and the Caribbean (selected countries) and fast-growing Asian countries: per capita GDP growth and some key factors explaining the difference, 1980-2003

(Percentages, except for RL and DIV indices)

\begin{tabular}{|c|c|c|c|c|c|}
\hline Countries & Per capita GDP growth rate & $\mathrm{I} / \mathrm{Y}$ & RL & DIV & $\mathrm{RX}^{*} \mathrm{DIV}$ \\
\hline Latin America & 0.4 & 20.2 & -0.27 & 0.71 & 1.9 \\
\hline Argentina & 0.3 & 18.1 & 0.28 & 0.86 & 3.4 \\
\hline Bolivia (Plurinational State of) & -0.2 & 16.0 & -0.66 & 0.73 & 1.3 \\
\hline Brazil & 0.8 & 20.8 & -0.26 & 0.90 & 5.2 \\
\hline Chile & 3.5 & 21.7 & 1.26 & 0.69 & 4.3 \\
\hline Colombia & 1.1 & 19.0 & -1.04 & 0.70 & 2.5 \\
\hline Costa Rica & 1.2 & 22.2 & 0.64 & 0.71 & 3.2 \\
\hline Ecuador & 0.3 & 21.1 & -0.39 & 0.58 & 2.0 \\
\hline El Salvador & 0.0 & 15.3 & -0.48 & 0.69 & 1.5 \\
\hline Guatemala & 0.0 & 15.0 & -0.64 & 0.75 & -0.5 \\
\hline Honduras & -0.1 & 25.1 & -0.85 & 0.62 & -1.2 \\
\hline Mexico & 1.0 & 22.4 & -0.12 & 0.82 & 6.5 \\
\hline Nicaragua & -1.3 & 23.9 & -0.68 & 0.71 & 0.1 \\
\hline Panama & 1.4 & 21.0 & -0.68 & 0.66 & -0.1 \\
\hline Paraguay & 0.1 & 24.0 & -0.50 & 0.62 & 1.5 \\
\hline Peru & 0.1 & 22.6 & -0.35 & 0.75 & 1.7 \\
\hline Uruguay & 0.1 & 14.7 & 0.53 & 0.81 & 3.0 \\
\hline Venezuela (Bol. Rep. of) & -1.1 & 21.2 & -0.66 & 0.41 & -0.1 \\
\hline Asian exporters of manufactures & 4.8 & 29.0 & 0.32 & 0.85 & 8.6 \\
\hline China & 8.2 & 36.0 & -0.45 & 0.92 & 18.1 \\
\hline Hong Kong (SAR) & 4.0 & 28.3 & 1.71 & 0.84 & 8.2 \\
\hline India & 3.8 & 22.6 & -0.01 & 0.86 & 6.6 \\
\hline Indonesia & 3.7 & 26.8 & -0.36 & 0.80 & 2.3 \\
\hline Republic of Korea & 5.6 & 32.4 & 0.81 & 0.87 & 10.0 \\
\hline Malaysia & 3.6 & 30.7 & 0.85 & 0.80 & 5.9 \\
\hline Thailand & 4.7 & 31.4 & 0.49 & 0.89 & 3.0 \\
\hline Vietnam & 4.7 & 23.6 & -0.50 & 0.78 & 15.0 \\
\hline
\end{tabular}

Source: World Bank, World Development Indicators [online database] http://devdata.worldbank.org/dataonline/, except for the HerfindahlHirschmann Index data, which are from United Nations Conference on Trade and Development (UNCTAD), Handbook of Trade and Development Statistics, Geneva.

N.B.: Underlying GDP and export data are in constant 2000 dollars. Exports refer to goods and services. The rule of law index is from Kaufman, Kraay and Mastruzzi (2005) and was measured in 1996.

Definition of variables:

$\mathrm{I} / \mathrm{Y}=$ gross fixed capital formation (average for the period) as a share of GDP.

RL = rule of law index (1996).

DIV = export diversification index (1- HHI), average for the period (data end in 2002).

$\mathrm{RX}^{*} \mathrm{DIV}=$ diversification-weighted rate of per capita export growth.

points higher. This latter difference arises out of the fact that exports are considerably more diversified in Asia than in Latin America and the Caribbean and, moreover, have grown faster.

Armed with these data, we undertook a simple calculation of the extent to which each of the three factors identified above (investment, the rule of law and export diversification) help to explain growth differentials between Latin America and the Caribbean and the fast growers of Asia. The results are shown in table 6 . About $80 \%$ of the difference in growth rates is explained by differences in investment rates, the rule of law and export diversification. Using the coefficients of equation (3) in table 4 (IV estimation), the main factor explaining growth differences turns out to be investment, with export diversification adding a not insignificant 0.7 percentage points to the superior Asian growth performance. When we use the coefficients of equation (4), diversification-weighted per capita export growth becomes the most important factor explaining growth differences. This factor by itself explains almost 50\% of the difference in growth rates between fast-growing Asian exporters of manufactures and Latin America and the Caribbean. We take this to be evidence that export growth, in the context of diversification, is the variable pulling GDP growth and investment. 


\begin{tabular}{lcc}
\hline & Calculation I & Calculation II \\
\hline Growth differential & 4.4 & 4.4 \\
Contribution of: & 2.2 & 1.0 \\
$\quad$ Investment & 0.6 & 0.5 \\
$\quad$ Rule of law & 0.7 & 2.1 \\
$\quad$ Export diversification & & 3.6 \\
$\quad$ Diversification-weighted per capita export growth & 3.5 & \\
Total of above factors & & \\
\hline
\end{tabular}

Source: results in table 4 and data in table 5 .

a In calculation I, the coefficients of equation (3, IV) were used; calculation II is based on the coefficients of equation (4, IV).

\section{VIII}

\section{Conclusions}

This paper has developed a theoretical model that attempts to capture the stylized facts of growth in economies that do not themselves innovate but catch up with the technological frontier by adding new activities to their production and export structures. The model suggests that export diversification, insofar as it is symptomatic of broadening comparative advantage, is the key to economic growth.

The empirical sections of the paper show that export diversification is indeed associated with higher economic growth. We speculate that there are two channels through which diversified export growth stimulates output growth. One of them we have called the portfolio effect. Diversification of exports leads to less export volatility, which in turn results in lowered output volatility. Countries with highly unstable economies grow more slowly than countries that exhibit more dampened cyclical fluctuations. The data do not contradict this chain of reasoning.

The second effect concerns the dynamic benefits associated with successful efforts to diversify comparative advantages, with learning and information externalities paramount among them. Our results are complementary to the recent findings of Hausmann and Klinger (2007) that a country's export pattern is a good predictor of future growth. Countries that export products associated with the export profile of high-income countries tend to converge rapidly towards those higher levels of income and, hence, to grow more rapidly. We would add that low-income countries generally have comparative advantages in few goods or, not unusually, just one. Efforts to diversify away from their traditional comparative advantage are likely to get the growth process started. It is only through output and export diversification that the spillovers of new exports can begin. These spillovers can be horizontal or vertical. Any new export produces information that is useful to other potential entrants into the industry. The emergence of a new sector facilitates the appearance of other sectors that utilize the same non-tradable inputs or public goods.

The empirical results are congruent with this model. In a cross-country econometric model of growth, the proxies for output and export diversification used (both the degree of export diversification and the interaction between per capita export growth and export diversification) are highly significant and make an important contribution to explaining variations in growth rates across countries.

The empirical model shows that variables other than export diversification also play a role in explaining 
differences in economic growth between countries. Investment certainly takes pride of place. It has already been noted that the dynamic Asian economies have investment rates considerably higher than those of the Latin American and Caribbean countries. The strength of investment could well be associated with export growth and diversification: the more diversified an economy is, the greater the likelihood that there will be profitable investment opportunities. In addition, where there is vigorous self-discovery there will also be vigorous investment. Finally, the more diversified exports are, the stronger will be the linkages between some exporting activities and the rest of the economy. ${ }^{20}$ In our empirical model, when diversification-weighted export growth is introduced as an explanatory variable, the quantitative importance of investment declines sharply. This may very well be an indication that rapid export growth cum diversification is a powerful incentive to investment.

(Original: English)

\footnotetext{
${ }^{20}$ However, investment and export diversification are not so highly correlated that their joint inclusion in the econometric model renders one of them not significant. In fact, the coefficient of the diversification variable is quite robust to the introduction of investment.
}

Agosin, M.R. (2007), "Trade and growth: why Asia grows faster than Latin America", Growth with Equity in Latin America, R. Ffrench-Davis and J.L. Machinea (eds.), Basingstoke, Palgrave-Macmillan.

(200(1999), "Trade and growth in Chile", CEPAL Review, No. 68 (LC/G.2039-P), Santiago, Chile, August.

Agosin, M.R. and C. Bravo-Ortega (2007), The Emergence of New Successful Export Activities in Chile, Washington, D.C., Inter-American Development Bank.

Amsden, A. (1989), Asia's Next Giant: South Korea and Late Industrialization, New York, Oxford University Press.

Gerschenkron, A. (1962), Economic Backwardness in Historical Perspective, Cambridge, Massachusetts, Harvard University Press.

Hausmann, R. and D. Rodrik (2006), Doomed to Choose: Industrial Policy as Predicament, Cambridge, Massachusetts, John F. Kennedy School of Government, Harvard University.

(200(2003), "Economic development as self-discovery", Journal of Development Economics, vol. 72, No. 2, Amsterdam, Elsevier.

Hausmann, R., D. Rodrik and A. Velasco (2005), Growth Diagnostics, Cambridge, Massachusetts, John F. Kennedy School of Government, Harvard University, unpublished.

Hausmann, R. and B. Klinger (2007), "The structure of the product space and the evolution of comparative advantage", CID Working Paper, No. 146, Center of International Development, Harvard University, April.
Imbs, J. and R. Wacziarg (2003), "Stages of diversification", American Economic Review, vol. 93, No. 1, Nashville, Tennessee, American Economic Association.

Jäntti, M., J. Saari and J. Vartiainen (2005), "Country case study: Finland. Combining growth with equity", document presented at the WIDER Jubilee Conference (Helsinki, 16-17 June 2005) [online] http://www.wider.unu.edu/conference/ conference-2005-3/conference-2005-3.htm.

Kaufmann, D., A. Kraay and M. Mastruzzi (2005), "Governance matters IV: governance indicators for 1996-2004", World Bank Policy Working Paper, No. 3630, Washington, D.C., World Bank, May.

Lewis, W.A. (1954), Economic Development with Unlimited Supplies of Labour, Manchester, The Manchester School, May.

Romer, P. (1993), "Two strategies for economic development: using ideas and producing ideas", Proceedings of the World Bank on Development Economics 1992, Washington, D.C., World Bank.

Vettas, N. (2000), "Investment dynamics in markets with endogenous demands", Journal of Industrial Economics, vol. 48, No. 2, Oxford, Blackwell Publishing.

Wade, R. (1990), Governing the Market: Economic Theory and the Role of Government in East Asian Industrialization, Princeton, Princeton University Press.

Wellisz, S. and P. Lam Shin Saw (1993), "Mauritius", The Political Economy of Poverty, Equity, and Growth: Five Small Open Economies, R. Findlay and S. Wellisz (eds.), Oxford, Oxford University Press. 